\title{
A functional androgen receptor is not sufficient to allow estradiol to protect bone after gonadectomy in estradiol receptor-deficient mice
}

\author{
Natalie A. Sims, ${ }^{1,2}$ Philippe Clément-Lacroix, ${ }^{3}$ Dominique Minet, ${ }^{3}$ \\ Caroline Fraslon-Vanhulle, ${ }^{4}$ Martine Gaillard-Kelly, ${ }^{4}$ Michèle Resche-Rigon, ${ }^{3}$ \\ and Roland Baron ${ }^{1,3}$

\begin{abstract}
${ }^{1}$ Departments of Orthopaedics and Cell Biology, Yale University School of Medicine, New Haven, Connecticut, USA ${ }^{2}$ Department of Medicine at St. Vincent's Hospital, The University of Melbourne, and St. Vincent's Institute of Medical Research, Fitzroy, Victoria, Australia ${ }^{3}$ ProSkelia Pharmaceuticals, Romainville, France
\end{abstract} \\ ${ }^{4}$ Aventis Pharma, Vitry, France
}

\begin{abstract}
Although the role of estradiol in maintaining bone mass is well established, the relative contributions of the estradiol receptors ER $\alpha$ and ER $\beta$ and of the androgen receptor (AR) remain controversial. To determine the role of ER $\alpha$-mediated, ER $\beta$-mediated, and non-ER-mediated mechanisms in maintaining bone mass, gonadectomy and estradiol treatment were studied in ER-knockout mice. Estradiol treatment of ovariectomized $E R \alpha \beta^{-/-}$mice failed to prevent bone loss, precluding significant effects of estradiol on bone through non-ER-signaling pathways. In contrast, estradiol prevented ovariectomy-induced bone loss in ER $\beta^{-/-}$mice, as in WT males and females, indicating that $\mathrm{ER} \alpha$ is the major mediator of estradiol effects in bone. No response of bone to estradiol was detected in orchidectomized $\mathrm{ER} \alpha^{-/-}$mice, suggesting estradiol cannot protect bone mass via the AR in vivo. In contrast to female $\mathrm{ER} \alpha \beta^{-/-}$and male $\mathrm{ER} \alpha^{-/-}$mice, female $\mathrm{ER} \alpha^{-/-}$mice were partially protected against ovariectomy-induced bone loss by estradiol, confirming that $\operatorname{ER} \beta$ mediates estradiol effects in bone, but only in females and with a lower efficacy than ER $\alpha$. We conclude that ER $\alpha$ is the main effector of estradiol's protective function in bone in both male and female mice, and that, in its absence, AR is not sufficient to mediate this response.
\end{abstract}

J. Clin. Invest. 111:1319-1327 (2003). doi:10.1172/JCI200317246.

\section{Introduction}

The decrease in circulating sex hormone levels after menopause is the major cause of osteoporosis in women and is initially associated with a high level of bone turnover (1). Both the bone loss and the high bone turnover can be prevented by estradiol treatment (2). Similarly, estradiol appears to regulate bone volume in men, since osteoporosis is observed in men and male rodents deficient in aromatase and in one man with a truncated, nonfunctional estradiol recep-

Received for publication October 25, 2002, and accepted in revised form February 12, 2003.

Address correspondence to: Roland Baron, Departments of Orthopaedics and Cell Biology, Yale University School of Medicine, SHM IE-55, 333 Cedar Street, New Haven, Connecticut 06520-8044, USA. Phone: (203) 785-4150; Fax: (203) 785-2744; E-mail: roland.baron@yale.edu.

Conflict of interest: The authors have declared that no conflict of interest exists.

Nonstandard abbreviations used: estradiol receptor (ER); androgen receptor (AR); trabecular bone volume (BV/TV); trabecular bone mineral density (Tb.BMD); peripheral quantitative computerized tomography (pQCT); osteoblast surface as percentage of trabecular bone surface (ObS/BS); osteoclast surface as percentage of trabecular bone surface $(\mathrm{OcS} / \mathrm{BS})$; bone formation rate as percentage of trabecular bone surface (BFR/BS). tor- $\alpha(E R \alpha)(3-5)$. Tissue response to estradiol is classically considered to be mediated by two ER subtypes: $E R \alpha$ and ER $\beta$. While both subtypes are expressed in bone (6-8), their relative functional importance remains unclear. Adding further complexity, it has also been suggested, based upon in vitro data, that estradiol may act in a nongenotropic manner via the androgen receptor (AR) in bone $(9,10)$. To address these questions, several groups, including ours, generated mutant mice in which ER subtypes were inactivated (11-13). Some of these mutants, however, express shortened ER transcripts that are able to bind estradiol and that have been shown recently to mediate at least the endothelial effects of estradiol (14-17). In contrast, the knockouts used here do not express any shortened transcripts with either ligand- or DNAbinding ability (18); this allowed us to determine the response of each ER-mediated or non-ER-mediated pathway to estradiol in vivo. Note that in order to distinguish between these models, we refer to the full knockouts as $\mathrm{ER} \alpha^{-/-}, \mathrm{ER} \beta^{-/-}$, and $\mathrm{ER} \alpha \beta^{-/-}$, and to the incomplete knockouts as $\alpha$ ERKO, $\beta$ ERKO, and $\alpha \beta E R K O$ following notation used previously.

Using the mutant mice in which ERs are fully deleted, we previously showed that deletion of $E R \alpha$, in both $E R \alpha$ and $E R \alpha \beta$ male knockouts, resulted in high tra- 
becular bone volume (BV/TV) and trabecular bone mineral density (Tb.BMD) in the presence of low bone turnover. Whereas ER $\beta$ deletion in males did not result in any modification of bone mass or turnover (13), both ER subtypes appeared to regulate bone turnover in female mice. High BV/TV and Tb.BMD were observed in $\mathrm{ER} \alpha^{-/-}$and $\mathrm{ER} \beta^{-/-}$females, while, in the absence of both receptors, BV/TV and Tb.BMD were low (13). The bone phenotype in these mice was complicated, however, by effects of ER deletion on the reproductive system; very high levels of circulating testosterone were observed in male and female ER $\alpha^{-/-}$ and male ER $\alpha \beta^{-/-}$mice, and very high circulating estradiol was detected in female $E R \alpha^{-/-}$mice (13).

In order to avoid such endocrine feedback mechanisms, and to determine the signaling pathways by which estradiol can protect bone from gonadectomyinduced bone loss, male and female knockout mice were gonadectomized and treated with estradiol. In addition, the contribution of elevated sex hormone levels to the bone phenotype of male and female ER $\alpha^{-/-}$ mice was determined by treatment of gonadectomized $\mathrm{ER} \alpha^{-/-}$mice with testosterone, antiestrogens, or antiandrogens. Our results clearly establish that in male mice, $E R \alpha$ is the only receptor that mediates the protective effects of estradiol, while in female mice, $E R \beta$ also plays a minor role. No response to estradiol via the remaining AR could be detected, even at suprapharmacological estradiol concentrations.

\section{Methods}

Generation and care of knockout mice. Knockout mice were generated and genotyped by PCR as described previously (18). Briefly, ER $\alpha^{-/-}$mice were generated by homologous recombination using three loxP sites flanking exon 3 (containing the first zinc finger of the DNA-binding domain) and a TKneo cassette to produce a fully disrupted ER $\alpha$ mutant. ER $\beta^{-/-}$mice were generated by insertion of a neo gene into exon 3 (also containing the first zinc finger of the DNA-binding domain). No alternately spliced mRNA transcripts were detected in $E R \alpha^{-/-}$mice, and while some were detected in ER $\beta^{-/-}$mice, no functional DNA- or ligandbinding domains were encoded. Animal care was in accordance with institutional guidelines. $\mathrm{ER} \alpha^{-/-}$mice were at backcross 6 at the time of experiment, and ER $\beta^{-/-}$mice were at backcross 4 , both onto the C57/B6 background. Due to the breeding difficulties in the $\mathrm{ER} \alpha \beta^{-/-}$mice, these were not backcrossed but had a $50 \%$ C57/B6 background. Littermate controls were used for all analyses.

Gonadectomies and hormonal manipulations. To determine the effects of gonadectomy, 12 -week-old mice were sham-operated, ovariectomized, or orchidectomized, and tissues were collected 4 or 8 weeks after operation for histomorphometric and densitometric analysis. For all hormonal manipulations, treatment was begun at the time of operation and continued until tissue collection. Since our previous data (13) estab- lished that $\mathrm{ER} \beta$ does not regulate $\mathrm{BV} / \mathrm{TV}$ in male mice, we limited hormonal manipulations of male mice to WT and ER $\alpha^{-/-}$only.

Estradiol was diluted in ethanol/corn oil (90:10), in order to slow down the release of the hormone, and administered by daily subcutaneous injection in WT, $E R \alpha^{-/-}$, and $E R \beta^{-/-}$females. Subcutaneous injections gave the following circulating levels of estradiol in ER $\alpha^{-/}$females: $24 \mathrm{pg} / \mathrm{ml}$ in sham-operated mice; 1 $\mathrm{pg} / \mathrm{ml}$ in ovariectomized mice; and 5, 20, 650, and $1,850 \mathrm{pg} / \mathrm{ml}$ in mice treated with $1,10,100$, and 1,000 $\mu \mathrm{g} / \mathrm{kg} / \mathrm{d}$ estradiol, respectively. Delivery of $1,10,100$, and $1,000 \mu \mathrm{g} / \mathrm{kg} / \mathrm{d}$ estradiol to ER $\alpha^{-/-}$female mice via implanted micropumps established average circulating estradiol levels of $25,80,570$, and $1,480 \mathrm{pg} / \mathrm{ml}$, respectively. In $E R \alpha^{-/-}$males and $E R \alpha \beta^{-/-}$females, in which we aimed to reach the highest possible exposures to the hormone, estradiol was administered by slow-release pellets (Innovative Research of America, Sarasota, Florida, USA). Pellets inserted subcutaneously gave, as an example, average circulating estradiol levels of $7 \mathrm{pg} / \mathrm{ml}$ in placebo-treated animals, $94 \mathrm{pg} / \mathrm{ml}$ in animals treated with $30 \mu \mathrm{g} / \mathrm{kg} / \mathrm{d}$, and $245 \mathrm{pg} / \mathrm{ml}$ in animals treated with $100 \mu \mathrm{g} / \mathrm{kg} / \mathrm{d}$. In males, testosterone propionate at $10 \mathrm{mg} / \mathrm{kg} / \mathrm{d}$ was administered by daily subcutaneous injection, and in females, a lower dose of $2.5 \mathrm{mg} / \mathrm{kg} / \mathrm{d}$ was administered by slow-release pellet (Innovative Research of America). Antiestrogen RU58668 (19) and antiandrogens RU58642 and RU50818 $(20,21)$ were administered at $10 \mathrm{mg} / \mathrm{kg} / \mathrm{d}$ and $30 \mathrm{mg} / \mathrm{kg} / \mathrm{d}$, respectively, by daily subcutaneous injection.

Peripheral quantitative computerized tomography. Densitometry was performed with the Stratec peripheral quantitative computerized tomography (pQCT) XCT Research SA+ (software version 5.4B; Norland Medical Systems Inc., White Plains, New York, USA) operating at a resolution of $70 \mu \mathrm{m}$. Metaphyseal pQCT scans of dissected right tibiae were performed to measure Tb.BMD. The scan was positioned in the metaphysis at a distance from the distal growth plate corresponding to $6 \%$ of the total length of the tibia (an area containing cortical and trabecular bone). We defined the trabecular bone region by setting an inner area to $60 \%$ of the total cross-sectional area, as described previously (13). The interassay coefficients of variation for the PQCT measurements were less than $2.5 \%$ (13).

Histomorphometry. Tibiae were collected at 4 or 8 weeks after operations, i.e., at 16 or 20 weeks of age, fixed in 3.7\% formaldehyde in PBS, and embedded in methylmethacrylate (22). Double fluorochrome labeling was performed as described previously (22). Fivemicrometer sections of the proximal metaphysis were stained with toluidine blue or analyzed unstained for fluorochrome labels. Histomorphometry was performed according to standard procedures in the proximal tibia using the OsteoMeasure system (OsteoMetrics Inc., Decatur, Georgia, USA). Tibial cortical thickness and periosteal mineral appositional rates were measured as described previously (22). 
a

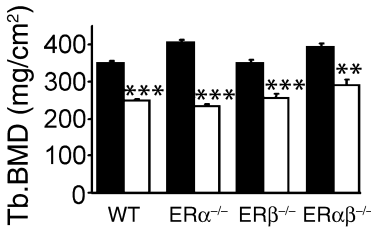

b

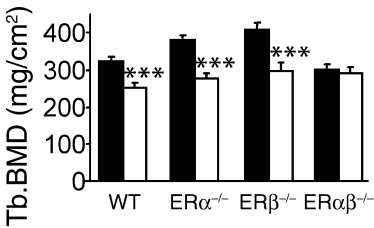

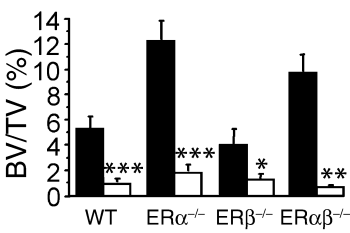

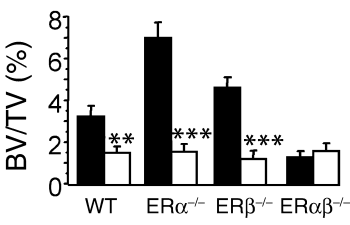

Figure 1

Response of WT and ER knockout mice to gonadectomy. Mice were sham-operated (black bars) or gonadectomized (white bars) at 12 weeks of age, and bones were collected after 8 weeks. (a) Tb.BMD and BV/TV were significantly reduced in male mice of all genotypes after orchidectomy. (b) Tb.BMD and BV/TV were significantly reduced after ovariectomy in female mice of all genotypes except ER $\alpha \beta^{-1-}$. Values are mean \pm SEM. ${ }^{*} P<0.05,{ }^{*} P<0.01$, $* * * P<0.001$ vs. sham-operated of the same genotype.
Serum and urinary biochemistry. Serum osteocalcin and urinary deoxypyridinoline cross-links were evaluated with kits from Biomedical Technologies Inc. (Stoughton, Massachusetts, USA) and Pacific Biometrics Inc. (Tampa, Florida, USA), respectively. Deoxypyridinoline cross-link values were divided by creatinine concentration to correct for water excretion. Serum estradiol and testosterone were measured using human RIA kits (ref. 2464-07 and 2463-07) adapted for mice (Immunotech, Marseille, France).

Quantification of sex hormone receptor levels. Femora of 12-week-old mice were pulverized under liquid nitrogen, and total RNA was extracted using a ToTALLY RNA kit (Ambion Inc., Austin, Texas, USA). The RNA was quantified spectrophotometrically, and the integrity of RNA preparations was examined by agarose gel electrophoresis. cDNA was synthesized using an Advantage RT-for-PCR kit (CLONTECH Laboratories Inc., Palo Alto, California, USA). Specific mRNAs for $E R \alpha, E R \beta, A R$, and $P R$ were measured by real-time quantitative RT-PCR using an ABI PRISM 7700 Sequence Detector system (Perkin-Elmer Applied Biosystems, Foster City, California, USA). A predeveloped TaqMan assay was used to quantify GAPDH. In addition, the following primers and probes for the different receptors were designed using Primer Express software (PerkinElmer Applied Biosystems): ER $\alpha$ forward primer, TGC TGG TTC AAG AGC GTC TTT; ER $\alpha$ reverse primer, GCG CCA CTC GAT CAT TCG; ER $\alpha$ probe, CTT CCG TCT TAC TGT CTC AGC CCT TGA CTT CT; ER $\beta$ forward primer, CGT AAT GAT ACC CAG ATG CAT AAT CA; ER $\beta$ reverse primer, CAG CCC TGT TAC TAG TCC AAG CA; ER $\beta$ probe, AAG AGG GAT GCT CAC TTC TGT GCC GCT; AR forward primer, CCA GCT CCT CCA
GAT CAG GAT; AR reverse primer, TGC CGG CCT CGT TCA A; AR probe, CAG CTG CTC CGC CGA CAT TAA; aromatase forward primer, TTT TTT CTT CTG AGG CCA AAT AGC; aromatase reverse primer, CGG GAC CAT GAT GGT GAC; aromatase probe, TCT TGG AAA TGC TGA ACC CCA TGC A.

Threshold cycle, which correlates inversely with target mRNA levels, was measured as the cycle number at which the reporter fluorescent emission increases above a threshold level. The expression data of all samples were normalized to GAPDH levels.
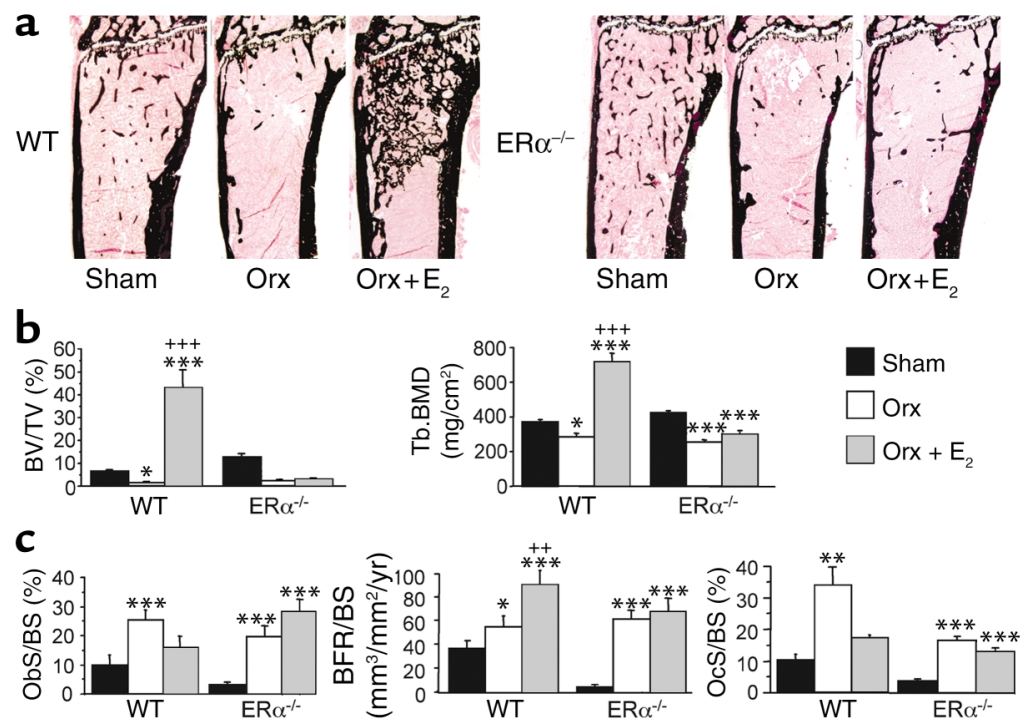

Figure 2

Male $E R \alpha^{-/-}$mice do not respond to estradiol $\left(E_{2}\right)$ treatment. (a) Representative von Kossa-stained sections of the proximal tibia from WT and $\mathrm{ER} \alpha^{-/-}$males sham-operated, orchidectomized (Orx), or orchidectomized and treated with slow-release pellets delivering $50 \mu \mathrm{g} / \mathrm{kg} / \mathrm{d}$ estradiol (Orx $+\mathrm{E}_{2}$ ). (b) BV/TV and Tb.BMD were increased after estradiol treatment in WT mice, but estradiol treatment did not alter BV/TV or Tb.BMD in $E R \alpha^{-/-}$males. (c) ObS/BS, bone formation rate expressed as a percentage of trabecular bone surface (BFR/BS), and OcS/BS were all elevated after orchidectomy in WT and $\mathrm{ER}^{-/-}$males. This was prevented by estradiol treatment in WT but not in $\mathrm{ER} \alpha^{-1-}$ males. The increased ObS/BS and OcS/BS were prevented by estradiol treatment in WT males, but not in $\mathrm{ER} \alpha^{-/-}$males. BFR/BS was further elevated in WT males treated with estradiol but remained unchanged in treated $E R \alpha^{-/-}$males. Values are mean \pm SEM. ${ }^{*} P<0.05,{ }^{*} P<0.01,{ }^{*}{ }^{*} P<0.001$ vs. sham-operated of the same genotype; ${ }^{++} P<0.01,{ }^{+++} P<0.001$ vs. Orx of the same genotype. 

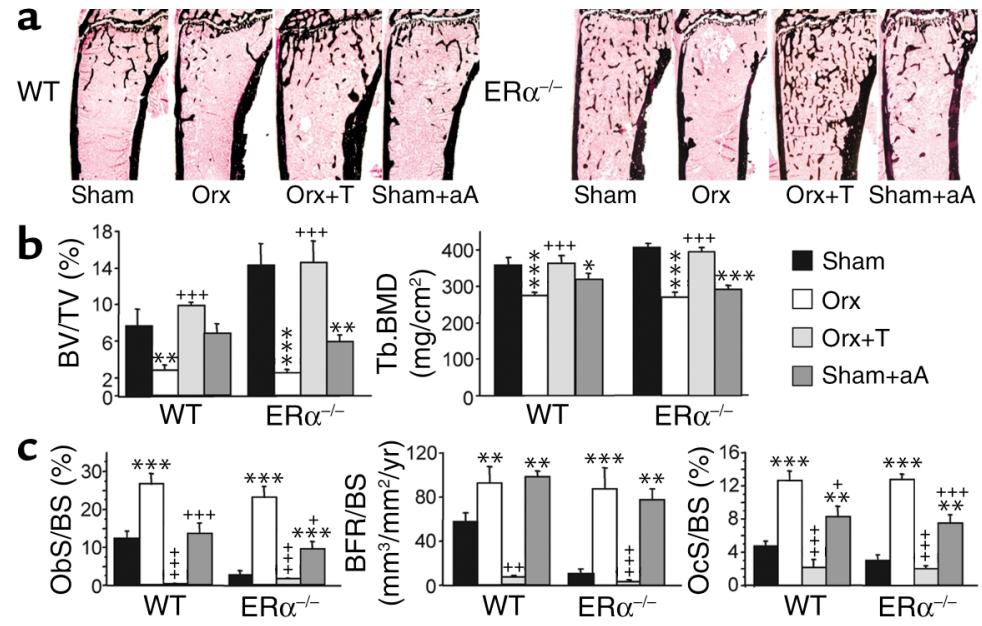

Figure 3

Testosterone prevents orchidectomy-induced bone loss in WT and ER $\alpha^{-/-}$males. Antiandrogen treatment partially reproduced the effects of orchidectomy. (a) Representative von Kossa-stained sections of the proximal tibia from WT (left) and $E R \alpha^{-/-}$(right) males that were sham-operated (Sham), orchidectomized (Orx), orchidectomized and treated with $10 \mathrm{mg} / \mathrm{kg} / \mathrm{d}$ subcutaneous propiotestosterone $(\mathrm{Orx}+\mathrm{T})$, or sham-operated and treated subcutaneously with the antiandrogen RU58642 (30 mg/kg/d) (Sham $+\mathrm{aA})$. (b) BV/TV and Tb.BMD were protected from bone loss after orchidectomy by testosterone treatment. Antiandrogen treatment partially reproduced the bone loss observed after orchidectomy when administered to sham-operated males of both genotypes. (c) The increased ObS/BS, BFR/BS, and OcS/BS after orchidectomy were prevented by testosterone treatment in both $\mathrm{WT}$ and $\mathrm{ER} \alpha^{-/-}$males. Antiandrogen treatment increased these markers of bone turnover in sham-operated males of both genotypes. Values are mean $\pm \mathrm{SEM}$. ${ }^{*} P<0.05,{ }^{*} P<0.01,{ }^{*}{ }^{*} P<0.001$ vs. sham-operated of the same genotype; ${ }^{+} P<0.05,{ }^{++} P<0.01,{ }^{++} P<0.001 \mathrm{vs}$. Orx of the same genotype.

\section{Results}

Effects of gonadectomy. Significant trabecular bone loss was observed after gonadectomy in all male knockouts and in female $E R \alpha^{-/-}$and ER $\beta^{-/-}$mice (Figure 1, a and b) and was associated with elevated bone turnover (see Figures $2 c, 3 c, 5 b, 6 c)$. In $E R \alpha \beta^{-/-}$females, the already low BV/TV was not reduced further (Figure $1 \mathrm{~b}$ ), nor was there any change in osteoblast surface or osteoclast surface as percentages of trabecular bone surface (ObS/BS, OcS/BS) after ovariectomy (mean ObS/BS \pm SEM: sham-operated, $19.9 \% \pm 5.0 \%$; ovariectomized, $23.9 \% \pm 5.5 \%$; mean $\mathrm{OcS} / \mathrm{BS} \pm \mathrm{SEM}$ : sham-operated, $14.1 \% \pm 2.7 \%$; ovariectomized, $14.1 \% \pm 1.5 \%$ ).

$E R \alpha$ is required for bone response to estradiol in males. Treatment of WT orchidectomized male mice with high-dose estradiol $(50 \mu \mathrm{g} / \mathrm{kg} / \mathrm{d}$, raising circulating levels to between 100 and $200 \mathrm{pg} / \mathrm{ml}$ ) not only prevented orchidectomy-associated bone loss but also elicited an increase in bone mass compared with that of shamoperated animals (Figure 2, a-c). BV/TV was elevated approximately fourfold (Figure $2 \mathrm{~b}$ ), and Tb.BMD was almost doubled (Figure $2 \mathrm{~b}$ ); these effects were associated with a reduction in bone turnover, indicated by lowered ObS/BS and OcS/BS (Figure 2c), as well as reduced serum osteocalcin and urinary deoxypyridinoline cross-links (data not shown). Surprisingly, despite these reductions in bone turnover, bone formation rate was elevated in estradioltreated male mice, possibly due to reduced removal of fluorochrome labels in the absence of normal osteoclastic bone resorption. In contrast, however, estradiol treatment did not prevent trabecular bone loss or the increased bone turnover associated with orchidectomy in $\mathrm{ER} \alpha^{-/-}$males (Figure 2, a and c). Furthermore, estradiol treatment of intact (non-orchidectomized) $\mathrm{ER} \alpha^{-/-}$males did not alter bone turnover, trabecular or cortical BMD, BV/TV, or cortical thickness (data not shown). These observations indicate that estradiol (and/or aromatized testosterone) is unable to play an osteoprotective role in males in the absence of $E R \alpha$, despite the presence of functional ARs. Thus, the bone loss observed after orchidectomy in these mice most likely relates to loss of protective effects of testosterone that act on the skeleton directly via the AR (see below).

Bone loss after orchidectomy of $E R \alpha^{-1-}$ mice is due to lack of testosterone. We therefore investigated the role of the high levels of circulating testosterone detected in $\mathrm{ER} \alpha^{-/-}$ males ( $5 \pm 1.9$ vs. $1.2 \pm 0.4 \mathrm{ng} / \mathrm{ml})$ (13) by treating male orchidectomized WT and $\mathrm{ER} \alpha^{-/-}$mice with a high dose of testosterone $(10 \mathrm{mg} / \mathrm{kg} / \mathrm{d}$, giving $22.8 \pm 3.4$ and $33.3 \pm 3.0 \mathrm{ng} / \mathrm{ml}$ circulating levels, respectively) or with antiandrogens. Testosterone treatment maintained BV/TV and Tb.BMD in both WT and $\mathrm{ER}^{-/-}$males (Figure 3, a and b). Testosterone treatment also maintained the low bone turnover characteristic of $\mathrm{ER}^{-/-}$males and reduced WT bone turnover to levels equivalent to those in $\mathrm{ER} \alpha^{-/-}$males (Figure 3, a-c). Treatment of non-orchidectomized WT and $E R \alpha^{-/-}$males with pure antiandrogens (RU58642
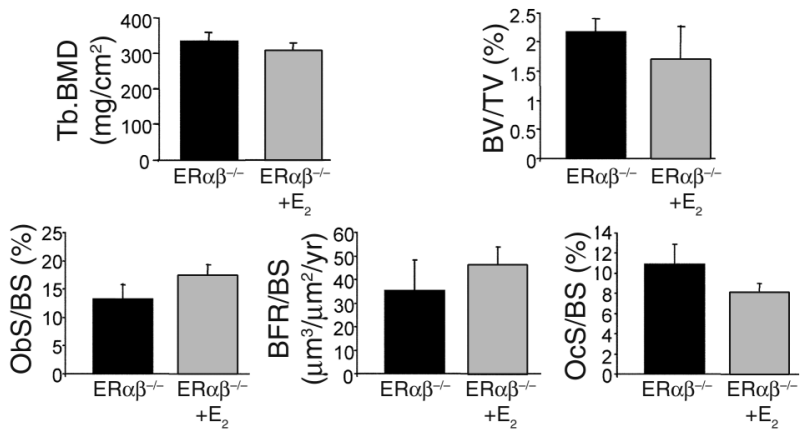

\section{Figure 4}

Estradiol treatment of female $E R \alpha \beta^{-/-}$mice does not significantly alter trabecular bone mass or bone turnover. Intact $E R \alpha \beta^{-/-}$females were implanted with slow-release pellets delivering estradiol at $30 \mu \mathrm{g} / \mathrm{kg} / \mathrm{d}$. Tb.BMD and BV/TV were not increased by high-dose estradiol treatment. No markers of bone turnover were significantly altered. Shown here are ObS/BS, BFR/BS, and OcS/BS. Values are mean \pm SEM. 

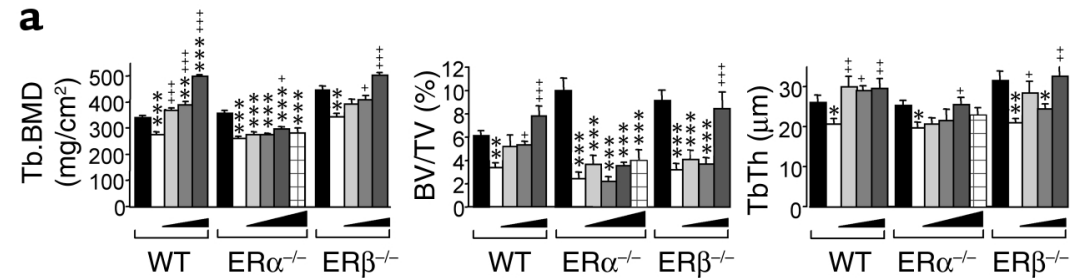

b

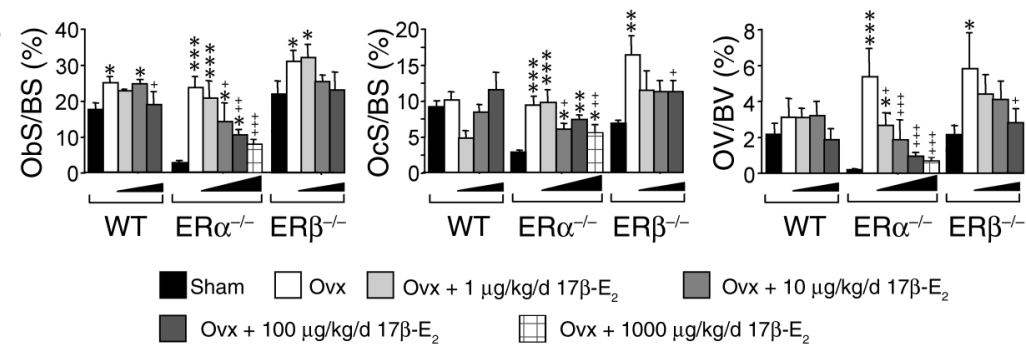

Figure 5

Estradiol treatment affected bone volume in a similar manner in WT and ER $\beta^{-/-}$females, but effects were less dramatic in $E R \alpha^{-/-}$females. (a) WT, $E R \alpha^{-/-}$, and $E R \beta^{-/-}$females were ovariectomized and treated with 1,10 , and $100 \mu \mathrm{g} / \mathrm{kg} / \mathrm{d} \mathrm{E}_{2} ; \mathrm{ER} \alpha^{-/-}$females were also treated with $1,000 \mu \mathrm{g} / \mathrm{kg} / \mathrm{d}$. Estradiol treatment of ovariectomized (Ovx)WT and ER $\beta^{-/-}$ females prevented trabecular bone loss associated with ovariectomy. In $E R \alpha^{-/-}$females, estradiol treatment at $100 \mu \mathrm{g} / \mathrm{kg} / \mathrm{d}$ was the only dosage at which estradiol prevented the reduction in Tb.BMD and trabecular thickness (TbTh), and still this effect was only partial. (b) In ER $\alpha^{-/-}$females, estradiol treatment reduced ObS/BS, OcS/BS, and osteoid volume (OV/BV) in a dose-dependent manner. Any effects of estradiol treatment on these parameters in WT and $E R \beta^{-/-}$females were less pronounced.Values are mean \pm SEM. ${ }^{*} P<0.05,{ }^{*} P<0.01,{ }^{*}{ }^{*} P<0.001$ vs. sham-operated of the same genotype; ${ }^{+} P<0.05$, ${ }^{++} P<0.01,{ }^{++} P<0.001$ vs. Ovx of the same genotype.

and RU50818) partially mimicked the effects of orchidectomy by reducing Tb.BMD and BV/TV and increasing bone turnover (effects of RU58642 are shown in Figure 3, a-c). Increased bone resorption was confirmed in WT and $\mathrm{ER} \alpha^{-/-}$males treated with antiandrogens by an increase in urinary deoxypyridinoline crosslinks (data not shown). In $\mathrm{ER} \alpha^{-/-}$males, in which circulating testosterone is markedly elevated (see above) (13), antiandrogens were also effective in mimicking castration. This suggests that it is indeed the high level of circulating testosterone that is osteoprotective in $E R \alpha^{-/-}$males and establishes the functionality of their ARs, thereby confirming that the protective effects of estradiol on the male skeleton require the presence of ER $\alpha$.

ER $\alpha$ is also required for bone responses to estradiol in females. In $E R \alpha \beta^{-/-}$females, not only did ovariectomy fail to decrease bone mass further (Figure 1), but estradiol, even at doses that increase bone mass in WT animals, failed to elicit any effect on trabecular bone (Figure 4) or cortical bone (not shown), indicating that the ability of the skeleton to respond to estradiol treatment had been entirely ablated with deletion of both ERs. Deletion of both receptors also prevented uterine response to estradiol (data not shown). Thus, the estradiol responses in bone and the uterus are clearly mediated by either or both ERs and can- not be mediated by non-ER-signaling pathways, such as AR. This allowed us to determine the physiological effects of estradiol on each receptor alone by treating the female single ER-knockout mice with estradiol.

$E R \beta$ facilitates the ER $\alpha$-mediated responses of bone to estradiol in females. In contrast to the double knockouts, estradiol treatment elicited a skeletal response in WT and in both singleER-knockout females. In WT females, as in male mice, trabecular $\mathrm{BMD}$ and $\mathrm{BV} / \mathrm{TV}$ were significantly elevated compared with those of sham-operated mice in response to high-dose estradiol treatment, while low doses of estradiol simply prevented the bone loss associated with ovariectomy (Figure 5a). This increase in bone mass was associated with a reduction in bone turnover, measured both by histomorphometry (Figure $5 \mathrm{~b}$ ) and by serum osteocalcin and urinary deoxypyridinoline cross-links (data not shown, and Table 1). A similar response was observed in the absence of $\operatorname{ER} \beta$, although a tenfold higher dose of estradiol was required to prevent ovariectomy-induced bone loss in ER $\beta^{-/-}$females (Figure $5 \mathrm{a}$ ), indicating that the remaining receptor, $\mathrm{ER} \alpha$, mediates most of the response to estradiol observed in WT females. These data also suggest that there may be a cooperation between the two receptors in eliciting the skeletal response, $E R \beta$ facilitating the effects of $E R \alpha$ in bone. Indeed, even in the absence of $E R \alpha$, protection against ovariectomy-induced changes in bone turnover was observed (Figure $5 \mathrm{~b}$ ), confirming that in the absence of $E R \alpha, E R \beta$ can mediate some of the effects of estradiol in the bones of female mice. Interestingly, however, this does not translate into a measurable

Table 1

Effects of estradiol treatment on bone resorption in ovariectomized WT, $E R \alpha^{-/-}$, and $E R \beta^{-/-}$females, as measured by urinary deoxypyridinoline cross-links ${ }^{\mathrm{A}}$

\begin{tabular}{llll}
\hline & WT & \multicolumn{1}{c}{ ER $\alpha^{-/-}$} & \multicolumn{1}{c}{ ER $\beta^{-/-}$} \\
Sham-operated & $30.3 \pm 2.19$ & $30.0 \pm 4.23$ & $21.4 \pm 1.12$ \\
Ovariectomized & $37.4 \pm 1.29^{\mathrm{B}}$ & $32.0 \pm 2.97$ & $30.5 \pm 1.77^{\mathrm{C}}$ \\
$E_{2} 1 \mu \mathrm{g} / \mathrm{kg} / \mathrm{d}$ s.c. & $36.8 \pm 7.22$ & $29.6 \pm 2.03$ & $25.4 \pm 1.71$ \\
$E_{2} 10 \mu \mathrm{g} / \mathrm{kg} / \mathrm{d}$ s.c. & $31.2 \pm 1.39^{\mathrm{B}}$ & $25.3 \pm 1.08$ & $21.3 \pm 0.8^{\mathrm{C}}$ \\
$2100 \mu \mathrm{g} / \mathrm{kg} / \mathrm{d}$ s.c. & $29.7 \pm 2.23^{\mathrm{B}}$ & $24.4 \pm 1.73$ & $19.7 \pm 0.99^{\mathrm{C}}$ \\
$E_{2} 1,000 \mu \mathrm{g} / \mathrm{kg} /$ d s.c. & & $23.4 \pm 1.84^{\mathrm{B}}$ &
\end{tabular}

${ }^{A}$ Data are expressed as mean nmol deoxypyridinoline/mmol creatinine \pm SEM. ${ }^{\mathrm{B}} P<0.05,{ }^{C} P<0.01$ vs. sham-operated (for ovariectomized group) or vs. ovariectomized (for estradiol-treated groups), by ANOVA followed by $t$ tests. s.c., subcutaneously. $E_{2}$, estradiol. 

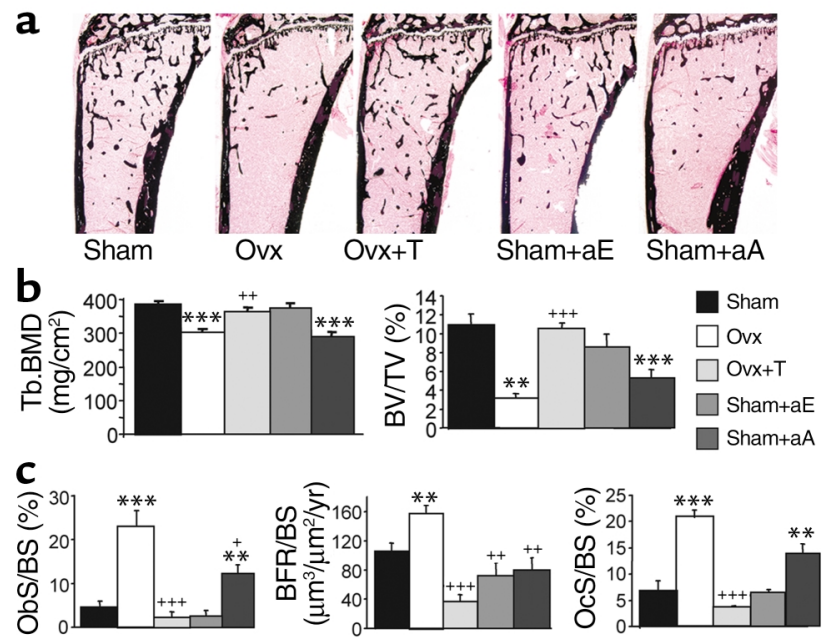

Figure 6

Testosterone treatment of $\mathrm{ER} \alpha^{-/-}$females prevents ovariectomyinduced bone loss and high bone turnover. Antiandrogen treatment, but not antiestrogen treatment, partially reproduces the effects of ovariectomy in ER $\alpha^{-/-}$females. (a) Representative von Kossa-stained sections of proximal tibiae from sham-operated mice, ovariectomized (Ovx) mice, ovariectomized mice implanted with pellets delivering $2.5 \mathrm{mg} / \mathrm{kg} / \mathrm{d}$ subcutaneous propiotestosterone $(\mathrm{Ovx}+\mathrm{T})$, and sham-operated females treated subcutaneously with the antiestrogen RU58668 $(10 \mathrm{mg} / \mathrm{kg} / \mathrm{d})(\mathrm{Sham}+\mathrm{aE})$ or the antiandrogen RU58642 $(30 \mathrm{mg} / \mathrm{kg} / \mathrm{d})($ Sham $+\mathrm{aA})$. (b) Testosterone treatment (light gray bars) prevented the ovariectomy-induced reduction in Tb.BMD and BV/TV in ER $\alpha^{-/-}$females. Antiandrogen treatment (dark gray bars), but not antiestrogen treatment (medium gray bars), reduced Tb.BMD and BV/TV to levels not significantly different from post-ovariectomy levels. (c) Testosterone treatment prevented the ovariectomy-induced increase in ObS/BS, BFR/BS, and OcS/BS in $E R \alpha^{-/-}$females. Antiandrogen, but not antiestrogen, treatment increased ObS/BS and OcS/BS. Values are mean \pm SEM. ${ }^{*} P<0.01$, ${ }^{*}{ }^{*} P<0.001 \mathrm{vs}$. sham-operated of the same genotype; ${ }^{+} P<0.05$, ${ }^{++} P<0.01,{ }^{+++} P<0.001$ vs. Ovx of the same genotype.

effect on bone volume (Figure $5 \mathrm{~b}$ ), probably because, as we suggested before (13), ER $\beta$ is not as efficient at reducing bone resorption (Figure 5 and Table 1).

$E R \alpha^{-1}$ females respond normally to testosterone treatment. Given that these results suggested that AR did not respond to estradiol in females, confirming what we observed also in males, we then tested for the presence of functional AR responses in these animals. Testosterone treatment in ovariectomized $\mathrm{ER} \alpha^{-/-}$mice maintained the high BV/TV and Tb.BMD characteristic of $\mathrm{ER} \alpha^{-/-}$females and, as in males, maintained a low bone turnover (Figure $6, \mathrm{a}-\mathrm{c}$ ). Since ER $\alpha^{-/-}$females demonstrate both high testosterone $(4.87 \pm 0.4 \mathrm{ng} / \mathrm{ml})$ and high estradiol levels $(96 \pm 16 \mathrm{pg} / \mathrm{ml})$, antiestrogen and antiandrogen treatment were then administered to determine whether either treatment could reproduce the effects of ovariectomy in ER $\alpha^{-/-}$females. In nonovariectomized female $\mathrm{ER}^{-/ /}$mice, as expected, antiestrogen treatment did not significantly alter bone volume or bone turnover, confirming in these animals that even high levels of estradiol are not capable of mediating any bone response in the absence of ER $\alpha$. In sharp contrast, antiandrogen treatment reduced $\mathrm{BV} / \mathrm{TV}$ and induced an increase in bone turnover, confirming (a) that testosterone plays an important role, acting via $A R$ rather than via ERs after aromatization, in determining the bone phenotype of $E R \alpha^{-/-}$females (Figure $6 \mathrm{a}-\mathrm{c}$ ), and (b) that the ARs expressed in $E R \alpha^{-/-}$ females are indeed functional.

Functional ARs are expressed at high levels in ER knockout mice. Given that all the results reported above indicated that estradiol cannot act in bone via the AR, despite its verified functionality, we needed to verify the levels of expression of the AR in the bone of these genetically altered mice. Real-time RT-PCR on RNA extracted from WT and knockout femora demonstrated that AR mRNA was elevated twofold in ER $\alpha^{-/-}$females, but present at normal levels in all other mutants. Expression levels of $E R \alpha, E R \beta$, and aromatase were not significantly altered in either male or female knockouts (Table 2). The functionality of these ARs in bone was demonstrated in the experiments reported above that show the ability of testosterone, but not estradiol, to elicit the proper bone responses after gonadectomy. Thus, even at high levels of AR expression, there were no protective effects of estradiol through the AR in female or male $\mathrm{ER} \alpha^{-/-}$mice.

\section{Discussion}

The importance of estrogens for the development, maturation, and maintenance of the skeleton is now well established; however, the exact contribution of each receptor subtype remains elusive. Initial analysis of the bone phenotype of $E R \alpha^{-/-}$, ER $\beta^{-/-}$, and ER $\alpha \beta^{-/-}$mice revealed that while ER $\beta$ was totally dispensable in males, both receptor subtypes participate in the control of bone turnover in females (13). In the present report, we show that in male mice, estradiol regulates trabecular bone remodeling exclusively through $\mathrm{ER} \alpha$, while in females both ER subtypes influence bone turnover and trabecular structure. Thus, in both males and females, $\mathrm{ER} \alpha$ is the main mediator of estradiol's protective effects in bone, and the AR, although expressed at high levels and functional in response to androgens in the same animals, is not able to mediate the effects of estradiol on bone in vivo in the absence of ER $\alpha$. We conclude that either the AR cannot mediate the bone responses to estradiol in vivo, or ER $\alpha$ is required to confer this property to the AR.

In male mice, trabecular bone loss occurred after orchidectomy in all ER knockouts, indicating that male gonadal hormones are responsible for the maintenance of $\mathrm{BV} / \mathrm{TV}$ even in the absence of estrogen receptors. This suggests that it is indeed testosterone binding to the $\mathrm{AR}$, and not estradiol derived from aromatization of testosterone and binding to ERs, that maintains bone mass in male mice. Kousteni et al. $(9,10)$, using in vitro studies, have recently suggested that estradiol, acting indifferently via the AR or the ERs, prevents osteoblast apoptosis via non-genotropic pathways. Whether or not this mechanism translates in vivo into 
the prevention of bone loss associated with gonadectomy in males and females remained to be tested. In apparent contradiction to this hypothesis, however, we show here that even a maximal dose of estradiol that is able to increase bone mass in intact mice is unable to prevent gonadectomy-induced bone loss when administered to male $\mathrm{ER} \alpha^{-/-}$mice. These in vivo data confirm that $\mathrm{ER} \alpha$ is required for the osteoprotective effects of estradiol in male mice and exclude a role of the AR in mediating these responses. Thus, the reported antiapoptotic effects of estradiol mediated through nongenotropic pathways $(9,10)$ are either irrelevant to bone responses in vivo or insufficient to protect against bone loss when ER $\alpha$ is inactivated. It remains, however, possible that the AR participates in these responses but only when ER $\alpha$ is expressed.

Furthermore, the fact that, in the absence of ER $\alpha$, high doses of estradiol were unable to prevent orchidectomy-induced bone loss in males further demonstrates that, like AR, and in contrast to the situation in females, $E R \beta$ is unresponsive to estradiol in males. This finding is consistent with our previous result showing the lack of a bone phenotype in male ER $\beta^{-/-}$mice, and the identical phenotypes of male $E R \alpha^{-/-}$and $E R \alpha \beta^{-/-}$mice (13).

In contrast to estradiol, however, and as expected, testosterone is capable of maintaining bone volume in males, independent of ER $\alpha$. We show here that testosterone treatment prevented orchidectomy-induced bone loss in both WT and ER $\alpha^{-/-}$males. This is consistent with effects of testosterone in vitro (23), in hypogonadic men $(24,25)$, and in $\alpha$ ERKO mice (26), clearly showing that testosterone inhibition of bone turnover and prevention of bone loss are not exclusively mediated by aromatization of testosterone into estradiol. Thus, these results show that the high circulating testosterone level in male $\mathrm{ER} \alpha^{-/-}$and $\mathrm{ER} \alpha \beta^{-/-}$mice is the main cause of the elevated BV/TV and low bone turnover observed in the gonad-intact knockouts (13). This was further confirmed by the fact that we can reproduce the effects of orchidectomy on bone by treat- ing intact $\mathrm{ER} \alpha^{-/-}$males with antiandrogens. While trabecular bone loss and high bone turnover were observed after antiandrogen treatment, this response was milder in WT males than in ER $\alpha^{-/-}$males. The weight of seminal vesicles was similarly decreased in antiandrogen-treated WT and $\mathrm{ER} \alpha^{-/-}$males (not shown), and circulating testosterone levels were not altered in either strain. Thus, in contrast to $E R \alpha^{-/-}$ males, in which trabecular bone mass is regulated strictly by androgens, both androgens and estrogens, acting through their respective specific receptors, regulate trabecular bone mass in WT males.

Gonadal hormones also played an osteoprotective role in single-ER-knockout females, but not in $E R \alpha \beta^{-/-}$ females, in which bone response to estradiol treatment was fully blocked. This result contrasts starkly with observations of ovariectomy-induced bone loss and osteoprotective actions of estradiol in $\alpha \beta E R K O$ mice (27), in which shortened transcripts of $E R \alpha$ that lack 64 residues located mainly in the $\mathrm{A} / \mathrm{B}$ region are still expressed $(14,15)$. This finding confirms that these shortened ER $\alpha$ 's respond to estradiol in a physiologically relevant manner and indicates that the activation function $A F 1$ of $E R \alpha$ is not required to mediate at least some of the effects of estradiol on trabecular bone. We, however, show here that full deletion of both receptors in $E R \alpha \beta^{-/-}$mice prevents the response to estradiol, thus excluding any effect of estradiol on bone metabolism in vivo through the $\operatorname{AR}(9,10)$ or through non-receptor-mediated pathways in females, as in males.

Since deletion of both ERs suppressed all effects of estradiol treatment in bone, estradiol responses of single ER knockouts can be interpreted as the physiological effects of the remaining receptor. In ER $\beta^{-/}$, where only ER $\alpha$ is expressed, any effect of estradiol treatment is mediated through ER $\alpha$, and vice versa. In WT mice, both receptors may respond to estradiol, and any effect observed would be the sum of these responses. Activation of $E R \beta$ in vivo, however, seems to require a higher concentration of estradiol than does activation of ER $\alpha$.

Table 2

Deletion of $\mathrm{ER} \alpha$, in $\mathrm{ER} \alpha^{-/-}$females, results in increased expression of AR mRNA

\begin{tabular}{|c|c|c|c|c|c|c|c|c|c|}
\hline & & \multicolumn{3}{|c|}{$\mathrm{ER} \alpha^{-/-}$} & \multicolumn{3}{|c|}{$E R \beta^{-/-}$} & \multicolumn{2}{|c|}{$E R \alpha \beta^{-/-}$} \\
\hline & & $\mathrm{C}_{\mathrm{t}}+/+$ & $C_{t}-/-$ & $\begin{array}{c}\text { Fold } \\
\text { difference }\end{array}$ & $\mathrm{C}_{\mathrm{t}}+/+$ & $C_{t}-/-$ & $\begin{array}{c}\text { Fold } \\
\text { difference }\end{array}$ & $\mathrm{C}_{\mathrm{t}}+/+$ & $C_{t}-/-$ \\
\hline \multirow[t]{2}{*}{$\mathrm{ER} \alpha$} & Female & ND & ND & & $18.10 \pm 0.23$ & $17.82 \pm 0.38$ & & ND & ND \\
\hline & Male & ND & ND & & $19.01 \pm 0.33$ & $18.27 \pm 0.22$ & & ND & ND \\
\hline \multirow[t]{2}{*}{ ER $\beta$} & Female & $21.30 \pm 0.45$ & $20.64 \pm 3.17$ & & ND & ND & & ND & ND \\
\hline & Male & $21.26 \pm 0.35$ & $21.18 \pm 0.48$ & & ND & ND & & ND & ND \\
\hline \multirow[t]{2}{*}{$A R$} & Female & $18.31 \pm 0.34$ & $17.30 \pm 0.33^{\mathrm{A}}$ & $\uparrow 2$ & $18.24 \pm 0.13$ & $19.53 \pm 0.39^{\mathrm{A}}$ & $\downarrow 2.45$ & $17.23 \pm 0.24$ & $16.94 \pm 0.22$ \\
\hline & Male & $18.99 \pm 0.16$ & $18.85 \pm 0.19$ & & $20.38 \pm 0.40$ & $20.08 \pm 0.30$ & & $17.50 \pm 0.14$ & $16.93 \pm 0.18$ \\
\hline \multirow[t]{2}{*}{ Aromatase } & Female & $20.82 \pm 0.55$ & $20.35 \pm 0.48$ & & $20.89 \pm 0.52$ & $21.75 \pm 0.36$ & & $21.46 \pm 0.31$ & $21.45 \pm 0.37$ \\
\hline & Male & $20.13 \pm 0.44$ & $20.24 \pm 0.44$ & & $22.10 \pm 0.46$ & $21.25 \pm 0.19$ & & $21.85 \pm 0.29$ & $21.97 \pm 0.70$ \\
\hline
\end{tabular}

Total mRNA was extracted from femora of 12-week-old females. Receptor mRNA was quantified by real-time RT-PCR in at least seven animals from each genotype. Fold change in receptor expression levels has been calculated from mean threshold cycle $\left(C_{t}\right)$ normalized to $G A P D H$. $C_{t}$ represents the PCR cycle number at which amplified product is detectable, and values are inversely proportional to the copy number of target RNA present in the sample. Fold differences are noted only where a significant difference in $C_{t}$ was observed. Values are mean \pm SEM. ${ }^{A} P<0.05$ vs. WT littermates. ND, not detected. 
This is consistent with in vitro studies showing that much higher levels of estradiol are required to activate estrogen-dependent transcription of an estrogenresponsive-element reporter construct via $E R \beta$ than via $E R \alpha(28)$. Our results, however, show that the presence of $E R \beta$ facilitates the response of $E R \alpha$ to estradiol on bone cells, although, alone, ER $\beta$ can maintain low bone turnover but not bone mass, probably because of its effects on bone resorption (13). Indeed, the response of trabecular bone to estradiol treatment was somewhat attenuated in ER $\beta^{-/-}$mice, suggesting that ER $\beta$ does play a role in the WT female response to estradiol. In ER $\alpha^{-/-}$females, where ER $\beta$ is the only receptor subtype present, a dose-dependent reduction in bone turnover was observed in response to estradiol treatment, indicating that estradiol can inhibit bone turnover via ER $\beta$ in vivo, but this did not translate into an increase in bone mass. The better protection of $\mathrm{BV} / \mathrm{TV}$ in WT than in ER $\beta^{-/-}$females suggests that $E R \alpha$ and $\operatorname{ER} \beta$ functions are not competitive but are most likely synergistic when both are expressed. This apparently contradicts our previous results showing decreased bone resorption in ER $\beta^{-/-}$females (13). However, since ovarian structure is altered, we cannot exclude alterations in other ovarian steroids, leading to decreased bone resorption in these females via the remaining ER $\alpha$. The results presented in this study indicate, in addition, that ER $\beta$ is less efficient than $E R \alpha$ at decreasing bone resorption. Thus, in states of increased bone turnover such as that in ovariectomized $E R \alpha^{-/-}$females, administered estradiol acting via ER $\beta$ can decrease both bone formation and bone resorption but does the latter less efficiently, leading to an imbalanced situation that favors bone resorption.

Since testosterone levels are also elevated in $E R \alpha^{-/-}$ females, the increased BV/TV and low bone turnover observed may also relate to a high level of circulating testosterone (although, notably, this level was not as high as that in $E R \alpha^{-/-}$males). As in male mice, testosterone treatment of $\mathrm{ER}^{-/-}$- females protected against both the bone loss and the high bone turnover associated with ovariectomy. This suggests that in females, as in males, testosterone is able to maintain a low level of bone turnover and high BV/TV.

Finally, the question of whether high testosterone or high estradiol levels determine the bone phenotype in intact $E R \alpha^{-/-}$females was investigated by treatment with pure antiestrogen or pure antiandrogen to determine which was able to reproduce the effects of ovariectomy. While antiestrogen treatment did not significantly alter BV/TV or bone turnover, antiandrogen treatment partially reproduced the effects of ovariectomy, confirming that testosterone is the major hormone responsible for the high $\mathrm{BV} / \mathrm{TV}$ in intact $\mathrm{ER} \alpha^{-/-}$ females. However, since testosterone levels in ER $\alpha^{-/-}$ females are much lower than those in $E R \alpha^{-/-}$males (13), and circulating levels of estradiol are very high, we cannot exclude that estradiol participates in the protection of bone via ER $\beta$ in these mice.
Thus, in the study of the effects of receptor knockouts in bone, the physiology of the whole animal needs to be considered. This is especially true in the case of the ER knockouts, in which a reproductive phenotype is observed (18) and in which testosterone and estradiol levels are elevated by ER $\alpha$ deletion (13). Taking these changes into consideration, we have determined that $E R \alpha$ is the major receptor regulating bone response to estradiol in both male and female mice. ER $\beta$ is able to play a minor protective role in female mice but does not participate in the response to estradiol in males. Furthermore, and most importantly, given the recent hypothesis that estradiol can act via the AR to protect bone, our results clearly demonstrate that the AR, although expressed and functional in $E R \alpha^{-/-}$males and females, cannot substitute for ER $\alpha$ to mediate estradiol protection against gonadectomy-induced bone loss in male or female mice.

\section{Acknowledgments}

The authors thank Pierre Chambon, Sonia Dupont, and Andree Krust for generating the knockout mice. We also thank Jennifer Juel for technical assistance in histology and morphometry. This work was supported in part by NIH grant DE-04724 to R. Baron, and in part by grants from Aventis Pharma and ProSkelia Pharmaceuticals to P. Clément-Lacroix and R. Baron.

1. Turner, R.T., Riggs, B.L., and Spelsberg, T.C. 1994. Skeletal effects of estrogen. Endocr. Rev. 15:275-300.

2. Lindsay, R., et al. 1976. Long-term prevention of postmenopausal osteoporosis by oestrogen. Evidence for an increased bone mass after delayed onset of oestrogen treatment. Lancet. 1:1038-1041.

3. Oz, O.K., et al. 2000. Bone has a sexually dimorphic response to aromatase deficiency. J. Bone Miner. Res. 15:507-514.

4. Miyaura, C., et al. 2001. Sex- and age-related response to aromatase deficiency in bone. Biochem. Biophys. Res. Commun. 280:1062-1068.

5. Rochira, V., Balestrieri, A., Faustini-Fustini, M., and Carani, C. 2001. Role of estrogen on bone in the human male: insights from the natural models of congenital estrogen deficiency. Mol. Cell. Endocrinol. 178:215-220.

6. Komm, B.S., et al. 1988. Estrogen binding, receptor mRNA, and biologic response in osteoblast-like osteosarcoma cells. Science. 241:81-84.

7. Onoe, Y., Miyaura, C., Ohta, H., Nozawa, S., and Suda, T. 1997. Expression of estrogen receptor beta in rat bone. Endocrinology. 138:4509-4512.

8. Vidal, O., Kindblom, L.G., and Ohlsson, C. 1999. Expression and localization of estrogen receptor-beta in murine and human bone. J. Bone Miner. Res. 14:923-929.

9. Kousteni, S., et al. 2001. Nongenotropic, sex-nonspecific signaling through the estrogen or androgen receptors: dissociation from transcriptional activity. Cell. 104:719-730.

10. Kousteni, S., et al. 2002. Reversal of bone loss in mice by nongenotropic signaling of sex steroids. Science. 298:843-846.

11. Windahl, S.H., et al. 2001. Female estrogen receptor beta-/- mice are partially protected against age-related trabecular bone loss. J. Bone Miner. Res. 16:1388-1398.

12. Vidal, O., et al. 2000. Estrogen receptor specificity in the regulation of skeletal growth and maturation in male mice. Proc. Natl. Acad. Sci. U. S. A. 97:5474-5479.

13. Sims, N.A., et al. 2002. Deletion of estrogen receptors reveals a regulatory role for estrogen receptors-beta in bone remodeling in females but not in males. Bone. 30:18-25.

14. Couse, J.F., et al. 1995. Analysis of transcription and estrogen insensitivity in the female mouse after targeted disruption of the estrogen receptor gene. Mol. Endocrinol. 9:1441-1454.

15. Denger, S., et al. 2001. ERalpha gene expression in human primary osteoblasts: evidence for the expression of two receptor proteins. Mol. Endocrinol. 15:2064-2077.

16. Krege, J.H., et al. 1998. Generation and reproductive phenotypes of mice lacking estrogen receptor beta. Proc. Natl. Acad. Sci. U. S. A. 95: $15677-15682$

17. Pendaries, C., et al. 2002. The AF-1 activation-function of ERalpha may 
be dispensable to mediate the effect of estradiol on endothelial NO production in mice. Proc. Natl. Acad. Sci. U. S. A. 99:2205-2210.

18. Dupont, S., et al. 2000. Effect of single and compound knockouts of estrogen receptors alpha (ERalpha) and beta (ERbeta) on mouse reproductive phenotypes. Development. 127:4277-4291.

19. Van de Velde, P., et al. 1996. RU 58,668: further in vitro and in vivo pharmacological data related to its antitumoral activity. J. Steroid Biochem. Mol. Biol. 59:449-457.

20. Battmann, T., et al. 1998. Pharmacological profile of RU 58642, a potent systemic antiandrogen for the treatment of androgen-dependent disorders. J. Steroid Biochem. Mol. Biol. 64:103-111.

21. Teutsch, G., et al. 1994. Non-steroidal antiandrogens: synthesis and biological profile of high-affinity ligands for the androgen receptor. J. Steroid Biochem. Mol. Biol. 48:111-119.

22. Sims, N.A., et al. 2000. Bone homeostasis in growth hormone receptor-null mice is restored by IGF-I but independent of Stat5. J. Clin. Invest. 106:1095-1103.

23. Hofbauer, L.C., Hicok, K.C., and Khosla, S. 1998. Effects of gonadal and adrenal androgens in a novel androgen-responsive human osteoblastic cell line. J. Cell. Biochem. 71:96-108.

24. Katznelson, L., et al. 1996. Increase in bone density and lean body mass during testosterone administration in men with acquired hypogonadism. J. Clin. Endocrinol. Metab. 81:4358-4365.

25. Anderson, F.H., Francis, R.M., Peaston, R.T., and Wastell, H.J. 1997. Androgen supplementation in eugonadal men with osteoporosis: effects of six months' treatment on markers of bone formation and resorption. J. Bone Miner. Res. 12:472-478.

26. Vandenput, L., et al. 2001. Testosterone prevents orchidectomy-induced bone loss in estrogen receptor-alpha knockout mice. Biochem. Biophys. Res. Commun. 285:70-76.

27. Gentile, M.A., Zhang, H., Harada, S., Rodan, G.A., and Kimmel, D.B. 2001. Bone response to estrogen replacement in OVX double estrogen receptor- $(\alpha$ and $\beta)$ knockout mice. J. Bone Miner. Res. 16(Suppl. 1):S146. (Abstr.)

28. Hall, J.M., and McDonnell, D.P. 1999. The estrogen receptor beta-isoform (ERbeta) of the human estrogen receptor modulates ERalpha transcriptional activity and is a key regulator of the cellular response to estrogens and antiestrogens. Endocrinology. 140:5566-5578. 